\title{
INVESTIGATION OF FOETAL MORTALITY ASSOCIATED WITH PLACENTA PRAEVIA
}

\author{
BY \\ R. G. RECORD AND THOMAS MCKEOWN \\ From the Department of Social Medicine, University of Birmingham
}

It is well known that a considerable part of the foetal mortality in placenta praevia is attributable to "prematurity", which is usually assessed on the basis of weight. The low weight is at least partly explained by the short gestation, but the possibility that it also results from retardation of foetal growth deserves attention. The decidua of the lower uterine segment is believed to be less vascular than that of the upper segment, and, although placentae attached to the lower segment are said to be larger than normal (Colmeiro-Laforet, 1953), it is not known whether this hypertrophy is sufficient to satisfy the demands of the foetus. In this communication we inquire to what extent low birth weight accounts for the high foetal mortality in placenta praevia and whether the low weight is wholly attributable to early delivery, or is also partly due to retardation of foetal growth.

The data assembled for this purpose also throw some light on the effect on foetal mortality of the modern tendency to adopt expectant methods of treatment. These methods were advocated by Macafee (1945) and Johnson (1945) in recognition of the high risk of foetal death associated with early delivery, and their observation that prolongation of pregnancy reduced the risks of the foetus without increasing those of the mother has been confirmed by others (Mills, 1948; Beilly, Greenberg, Aaron, and Peck, 1952). Examination of the influence of expectant treatment is complicated by the fact that during the last decade there have been other changes in the management of these cases. There has been an increasing tendency to treat placenta praevia, even the less severe types, by Caesarean section, and to avoid resort to hydrostatic bags, Willett's forceps, and version in cases delivered vaginally.

We have no information about the effect of changes in treatment on maternal mortality. The frequency of maternal death in placenta praevia is now so low that a very large series of cases would be required for this purpose.

\section{MATERIAL}

Sources of data are described in the preceding investigation of the association between incidence of placenta praevia and maternal age and parity. Briefly, information was sought about all cases delivered in Birmingham in the 11- year period 1942-52, by examination of the records of five maternity hospitals and two general hospitals. The only cases missed are believed to have been a small number before 1946 and in 1952 in some of the smaller hospitals, and there is no reason to suppose that their omission makes the series unrepresentative. Adequate data about control populations of births are available from earlier investigations in Birmingham, both of a large unselected series of hospital deliveries during several years, and of all deliveries in the city in one year (1947). For comparison of weight, the control group has been restricted to hospital births, since domiciliary weighings are less accurate. For investigation of duration of gestation and foetal mortality, the control group consisted of all Birmingham births in 1947, the mid-year of the period studied.

The number of cases for which data were available are shown according to type in Table I.

There were 971 single pregnancies, after exclusion of nineteen sets of twins and 33 single births for which information was very incomplete. Weight was known in respect of 873, and duration of gestation in respect of 837 .

TABLE I

DETAILS OF 1,023 CASES OF PLACENTA PRAEVIA IDENTIFIED IN BIRMINGHAM HOSPITAL RECORDS 1942-52

\begin{tabular}{|c|c|c|c|c|c|}
\hline Type of Placenta Praevia & 1 & 2 & 3 and 4 & Unspecified & Total \\
\hline $\begin{array}{l}\text { Total number of Cases.. } \\
\text { Cases with no Data } \\
\text { Twins } \\
\begin{array}{llll} & \text {. } & \text {.. } \\
\end{array}\end{array}$ & $\begin{array}{r}401 \\
13 \\
6\end{array}$ & $\begin{array}{r}298 \\
11 \\
8\end{array}$ & $\begin{array}{r}283 \\
8 \\
3\end{array}$ & $\begin{array}{r}41 \\
1 \\
2\end{array}$ & $\begin{array}{r}1,023 \\
33 \\
19 \\
\end{array}$ \\
\hline Single Births & 382 & 279 & 272 & 38 & 971 \\
\hline $\begin{array}{cc}\text { Single Births of Known } \\
\text { Weight }\end{array}$ & 352 & 247 & 236 & 38 & 873 \\
\hline $\begin{array}{c}\text { Single Births of Known } \\
\text { Gestation }\end{array}$ & 327 & 242 & 237 & 31 & 837 \\
\hline
\end{tabular}

\section{Mortality Related to BiRTH Weight}

Among 971 cases of placenta praevia in single pregnancies delivered in Birmingham hospitals during the 11-year period, there were 144 stillbirths and 87 neonatal deaths in hospital of liveborn children. The mortality rate was 238 (stillbirths and neonatal deaths in hospital) per 1,000 total births. No strictly comparable figure is available for all 
single births; among 22,454 single births in Birmingham during 1947 there were 39 stillbirths and neonatal deaths per 1,000 total births. The proportion of neonatal deaths which occur in hospital is high enough to make this experience acceptable for purposes of comparison.

The mean weight was $6.30 \mathrm{lb}$. for 873 births associated with placenta praevia, and $7 \cdot 16 \mathrm{lb}$. for 13,020 Birmingham hospital single births (Table II). Differences in foetal weight associated with the different types of placenta praevia were trivial.

TABLE II

FOETAL WEIGHT IN PLACENTA PRAEVIA

\begin{tabular}{|c|c|c|c|}
\hline $\begin{array}{c}\text { Type of Placenta } \\
\text { Praevia }\end{array}$ & No. & $\begin{array}{l}\text { Mean Weight } \\
\text { (lb.) }\end{array}$ & $\begin{array}{l}\text { Difference between } \\
\text { Means }\end{array}$ \\
\hline 1 & 352 & $6 \cdot 33$ & \\
\hline 2 & 247 & $6 \cdot 15$ & $0.10 \pm 0.13$ \\
\hline 3 and 4 & 236 & $6 \cdot 32$ & $0.17 \pm 0.14$ \\
\hline Unspecified & 38 & . & \\
\hline Total $\ldots$ & 873 & $6 \cdot 30$ & \\
\hline $\begin{array}{l}\text { All Hospital Single } \\
\text { Births* }\end{array}$ & 13,020 & $7 \cdot 16$ & $0.86 \pm 0.04$ \\
\hline
\end{tabular}

Mortality is of course greater for births associated with placenta praevia than for all single births, even when comparison is restricted to births of corresponding weight (Table III). As would be expected the difference is small in the case of births of low weight (under $4 \mathrm{lb}$.) for which mortality is very high. At all weights above $4 \mathrm{lb}$. mortality is much greater in placenta praevia, and the difference increases as weight increases.

We have attempted to assess the contribution of low birth weight to the total mortality in placenta praevia. The mortality rate based on 22,454 Birmingham births was standardized to correspond to the weight distribution of the 873 births associated with placenta praevia. By this procedure the mortality of all single births was raised from 39 to 118 (per 1,000 total births), which may be compared with the rate observed in cases of placenta praevia $(238$ per 1,000$)$. This suggests that about half the increased mortality in placenta praevia is attributable to low birth weight.

\section{INFLUENCE OF DURATION OF GESTATION AND RATE OF} Foetal Growth ON BiRTh WeIGHT

We now inquire whether the low birth weight in placenta praevia is wholly attributable to early delivery or is due partly to retardation of foetal growth. Mean duration of gestation was 260.4 days for 837 cases of placenta praevia, and $280 \cdot 5$ for 17,072 single births in Birmingham during 1947 (Table IV). There was also a significant difference between Type 1 and Type 2, but not between Type 2 and Types 3 and 4.

TABLE IV

DURATION OF GESTATION IN PLACENTA PRAEVIA

\begin{tabular}{|c|c|c|c|}
\hline $\begin{array}{c}\text { Type of Placenta } \\
\text { Praevia }\end{array}$ & $\begin{array}{l}\text { No. of } \\
\text { Foetuses }\end{array}$ & $\begin{array}{c}\text { Mean Duration } \\
\text { of Gestation } \\
\text { (days) }\end{array}$ & $\begin{array}{c}\text { Difference } \\
\text { between } \\
\text { Means }\end{array}$ \\
\hline 1 & 327 & $263 \cdot 2$ & \\
\hline 2 & 242 & $258 \cdot 7$ & \\
\hline 3 and 4 & 237 & $258 \cdot 2$ & \\
\hline Unspecified & 31 & .. & \\
\hline $\begin{array}{l}\text { Total } \\
\text { All Single Births in } \\
\text { Birmingham, 1947* }\end{array}$ & $\begin{array}{r}837 \\
17,072\end{array}$ & $\begin{array}{l}260 \cdot 4 \\
280 \cdot 5\end{array}$ & $20 \cdot 1 \pm 0.6$ \\
\hline
\end{tabular}

* Gibson and McKeown (1950).

The data in Table $\mathrm{V}$ (opposite) suggest that the low birth weight in placenta praevia is almost wholly attributable to the short period of gestation,

TABLE III

FOETAL MORTALITY RATES* ACCORDING TO BIRTH WEIGHT

\begin{tabular}{|c|c|c|c|c|c|c|c|c|c|c|}
\hline \multirow{2}{*}{\multicolumn{4}{|c|}{$\begin{array}{c}\text { Birth Weight } \\
\text { (lb.) }\end{array}$}} & \multicolumn{5}{|c|}{ Type of Placenta Praevia } & \multirow{2}{*}{$\begin{array}{c}\text { All Single Births in } \\
\text { Birmingham, 1947† } \\
\text { (b) }\end{array}$} & \multirow{3}{*}{$\frac{(a) \div(b)}{1.01}$} \\
\hline & & & & 1 & 2 & 3 and 4 & Unspecified & $\begin{array}{c}\text { Total } \\
(a)\end{array}$ & & \\
\hline Under 4 & $\cdots$ & $\cdots$ & . & 731 (26) & 791 (24) & 786 (14) & $-(7)$ & 732 (71) & 723 (289) & \\
\hline 4 & $\cdots$ & $\cdots$ & $\cdots$ & 423 (26) & 676 (34) & $300(30)$ & . - (6) & 458 (96) & $242 \quad$ (393) & $1 \cdot 89$ \\
\hline $5-$ & $\cdots$ & $\cdots$ & . & 197 (61) & 255 (51) & 200 (45) & $-(6)$ & 209 (163) & $93(1,557)$ & $2 \cdot 25$ \\
\hline $6-$ & $\ldots$ & $\cdots$ & . & $147(102)$ & 167 (54) & $95(63)$ & $-(7)$ & $137(226)$ & $30(5,187)$ & $4 \cdot 57$ \\
\hline $7-$ & $\cdots$ & $\cdots$ & $\cdots$ & 88 (91) & 143 (56) & 94 (64) & - (8) & $100(219)$ & $21(7,975)$ & $4 \cdot 76$ \\
\hline 8 and Over & . & . & . & $65(46)$ & 143 (28) & $50(20)$ & - (4) & $102(98)$ & $16(7,053)$ & $6 \cdot 37$ \\
\hline Unknown & $\cdots$ & . & $\cdots$ & $300(30)$ & $406 \quad(32)$ & 444 (36) & $-(0)$ & 388 (98) & - & - \\
\hline Total ... & $\ldots$ & $\ldots$ & $\ldots$ & $202(382)$ & 319 (279) & $213(272)$ & $184 \quad(38)$ & 238 (971) & $39(22,454)$ & $5 \cdot 29$ \\
\hline
\end{tabular}


TABLE V

MEAN FOETAL WEIGHT ACCORDING TO DURATION OF GESTATION

\begin{tabular}{|c|c|c|c|c|c|c|c|c|}
\hline \multirow{2}{*}{\multicolumn{4}{|c|}{$\begin{array}{l}\text { Duration of } \\
\text { Gestation } \\
\text { (wks) }\end{array}$}} & \multicolumn{3}{|c|}{ Placenta Praevia } & \multicolumn{2}{|c|}{ Hospital Single Births* } \\
\hline & & & & No. of Foetuses & $\begin{array}{l}\text { Mean Duration of } \\
\text { Gestation (days) }\end{array}$ & $\begin{array}{c}\text { Mean Foetal Weight } \\
\text { (lb.) }\end{array}$ & $\begin{array}{l}\text { Mean Duration of } \\
\text { Gestation (days) }\end{array}$ & $\begin{array}{c}\text { Mean Standardized } \\
\text { Foetal Weight } f \text { (lb.) }\end{array}$ \\
\hline $32-$ & $\cdots$ & $\cdots$ & $\cdots$ & 62 & $230 \cdot 9$ & $4 \cdot 53$ & $231 \cdot 7$ & $4 \cdot 16$ \\
\hline 34 & $\cdots$ & $\cdots$ & $\cdots$ & 90 & $244 \cdot 9$ & $5 \cdot 33$ & $246 \cdot 0$ & $5 \cdot 42$ \\
\hline $36-$ & $\cdots$ & $\cdots$ & $\cdots$ & 166 & $258 \cdot 9$ & $6 \cdot 40$ & $259 \cdot 9$ & $6 \cdot 42$ \\
\hline $38-$ & $\cdots$ & $\cdots$ & $\cdots$ & 222 & $272 \cdot 6$ & $6 \cdot 82$ & $274 \cdot 2$ & $7 \cdot 14$ \\
\hline $40-$ & $\cdots$ & $\cdots$ & $\cdots$ & 126 & $285 \cdot 0$ & $7 \cdot 39$ & $285 \cdot 5$ & $7 \cdot 59$ \\
\hline 42- & $\cdots$ & $\cdots$ & $\cdots$ & 37 & $298 \cdot 5$ & $7 \cdot 88$ & $298 \cdot 3$ & $7 \cdot 76$ \\
\hline
\end{tabular}

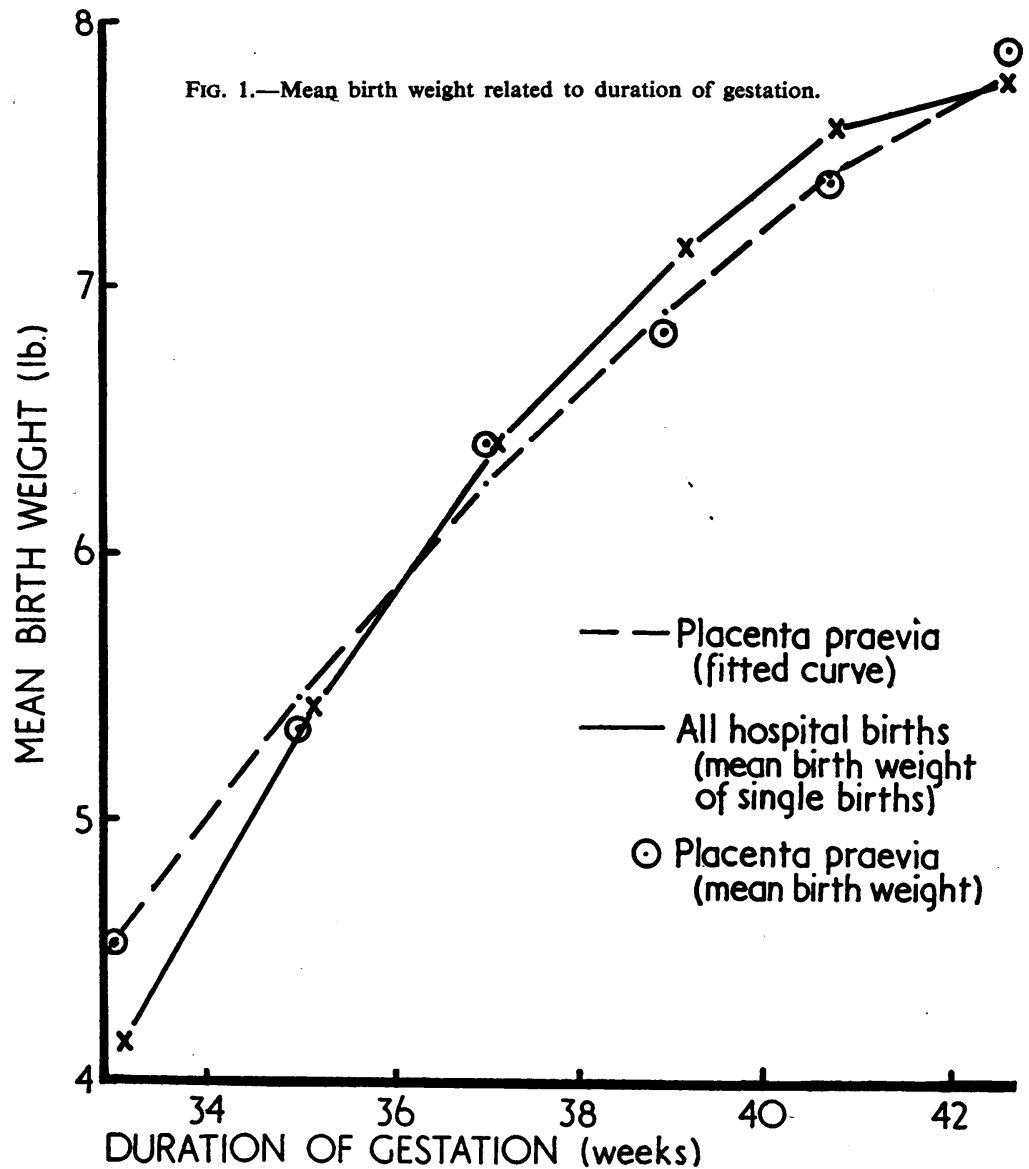

gestation of less than 32 weeks have been excluded since numbers are small. When the mean birth weights of the placenta praevia series are plotted, some irregularities are revealed. These can probably be ascribed to small numbers, particularly at the extremes of the distribution. A smooth curve of quadratic type, calculated by the method of least squares has therefore been fitted (Fig. 1). This suggests that growth of foetuses associated with placenta praevia is slightly retarded from about 37 weeks' gestation, but retardation does not appear to be sufficiently marked to have any considerable effect on birth weight. This conclusion is confirmed by the results of standardization to correct the mean foetal weights for differences in duration of gestation and parity (Table VI, overleaf). After this procedure the difference between mean weights of births associated with placenta praevia and all hospital single births is only $0 \cdot 11 \mathrm{lb}$. After standardization there are no significant differences between mean weights

since at corresponding periods weight differences between foetuses associated with placenta praevia and hospital single births are small. For the purposes of this comparison, mean foetal weights of hospital births have been standardized to the distribution by sex and parity of the placenta praevia series. Cases of of foetuses $1 \mathrm{ll}$ the different types of placenta praevia.

It is concluded that foetal growth in placenta praevia is slightly retarded, but this accounts for only a small part of the difference in birth weight, which is mainly attributable to early delivery. 
TABLE VI

MEAN FOETAL WEIGHTS STANDARDIZED* FOR DURATION OF GESTATION AND PARITY

\begin{tabular}{|c|c|c|c|}
\hline $\begin{array}{c}\text { Type of Placenta } \\
\text { Praevia }\end{array}$ & $\begin{array}{l}\text { No. of } \\
\text { Foetuses }\end{array}$ & $\begin{array}{c}\text { Standardized } \\
\text { Mean Weight } \\
\text { (lb.) }\end{array}$ & $\begin{array}{l}\text { Difference } \\
\text { between } \\
\text { Means }\end{array}$ \\
\hline 1 & 285 & $6 \cdot 47$ & \multirow{4}{*}{$\begin{array}{l}0.03 \pm 0.13 \\
0.11 \pm 0.14\end{array}$} \\
\hline 2 & 195 & $6 \cdot 44$ & \\
\hline 3 and 4 & 194 & $6 \cdot 55$ & \\
\hline Unspecified & 29 & $\ldots$ & \\
\hline \multirow{2}{*}{$\begin{array}{c}\text { Total } \\
\text { All Hospital Single } \\
\text { Birthst }\end{array}$} & 703 & $6 \cdot 49$ & \multirow{2}{*}{$0.11 \pm 0.05$} \\
\hline & 12,702 & $6 \cdot 60$ & \\
\hline
\end{tabular}

* Means have been standardized to the distribution by gestation and parity of the complete placenta praevia series.

$\dagger$ McKeown and Record (1953).

\section{Secular Trend of Foetal Mortality}

Fig. 2 shows that there has been a fairly marked decline in foetal mortality (expressed as the number of stillbirths and neonatal deaths in hospital per 1,000 total births) during the 11 -year period; it fell from 345 in 1942-3 to 181 in 1950-52. The improvement has been restricted to vaginal deliveries, but since this result is undoubtedly influenced by the type and proportion of cases selected for Caesarean delivery, not much significance can be attached to it. The fall in mortality has been marked in Types 1 and 2 , but is not present in Types 3 and 4 (Fig. 3, opposite).

The data available enable us to explore two possible influences on the decline of mortality:

(a) greater use of expectant treatment;

(b) higher incidence of abdominal delivery.

It is clear that a strong association may be expected between foetal mortality and duration of gestation. The foetal mortality, in fact, shows a consistent fall with increasing gestation to 106 (per 1,000 total births) at 38-39 weeks (Table VII).

TABLE VII

FOETAL MORTALITY RATES ACCORDING TO DURATION OF GESTATION

\begin{tabular}{|c|c|c|c|c|c|c|}
\hline \multirow{2}{*}{\multicolumn{2}{|c|}{$\begin{array}{c}\text { Duration } \\
\text { of } \\
\text { Gestation } \\
\text { (wks) }\end{array}$}} & \multicolumn{5}{|c|}{ Type of Placenta Praevia } \\
\hline & & 1 & 2 & 3 and 4 & $\begin{array}{l}\text { Unspeci- } \\
\text { fied }\end{array}$ & Total \\
\hline Unde & & - (5) & - (2) & $-(1)$ & $-(0)$ & $1,000 \quad(8)$ \\
\hline 28- & . & $471 \quad(17)$ & 591 (22) & $846 \quad(13)$ & - (1) & $623(53)$ \\
\hline $32-$ & . & $328 \quad(61)$ & $439 \quad(57)$ & $358 \quad(67)$ & - (9) & $361(194)$ \\
\hline $36-$ & .. & $\begin{array}{|ll|}159 & (63) \\
\end{array}$ & 204 (49) & $129 \quad(62)$ & $-(10)$ & $158(184)$ \\
\hline 38 & .. & $82(97)$ & $157(70)$ & $91 \quad(55)$ & $-(5)$ & $106(227)$ \\
\hline 40 & . & $143 \quad(84)$ & $190 \quad(42)$ & 77 (39) & $-(6)$ & $135(171)$ \\
\hline$\overline{\text { Unkn }}$ & & $255(55)$ & $541 \quad(37)$ & $171 \quad(35)$ & $-(7)$ & $328(134)$ \\
\hline Total & . & $202(382)$ & 319 (279) & $213(272)$ & $184(38)$ & $238(971)$ \\
\hline
\end{tabular}

During the 11-year period there has been a $8 \overrightarrow{0}$ conspicuous increase in the mean duration of pregnancies associated with placenta praevia (Table VIII), from $254 \cdot 1$ days in $1942-3$ to $262 \cdot 8$ days in

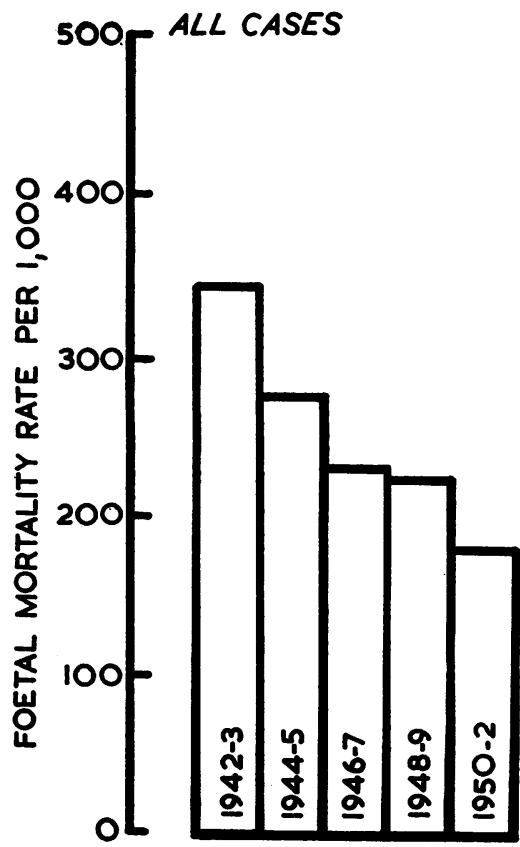

VAGINAL DELIVERIES

CAESAREAN DELIVERIES

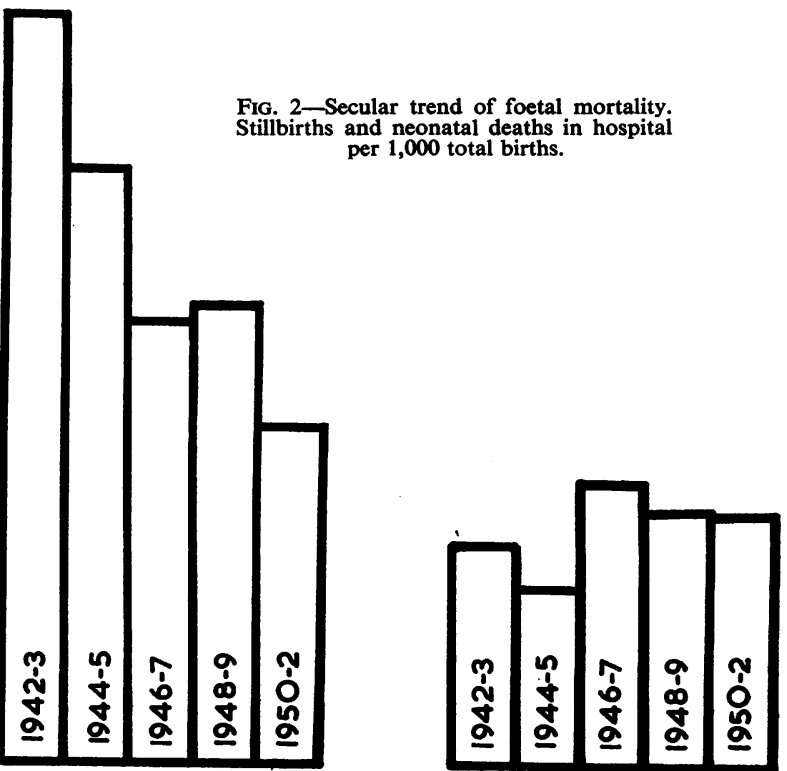




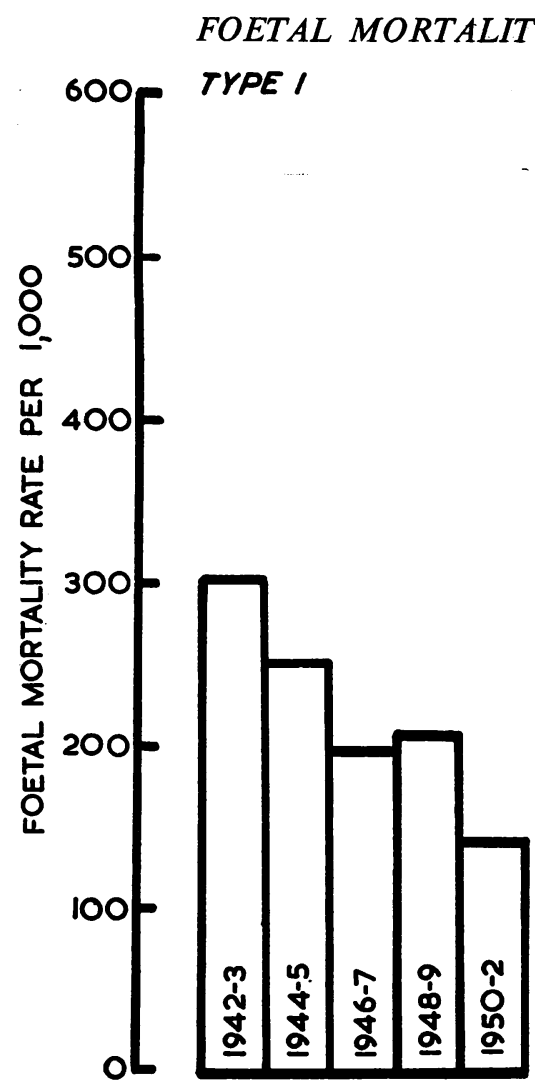

TYPE 2

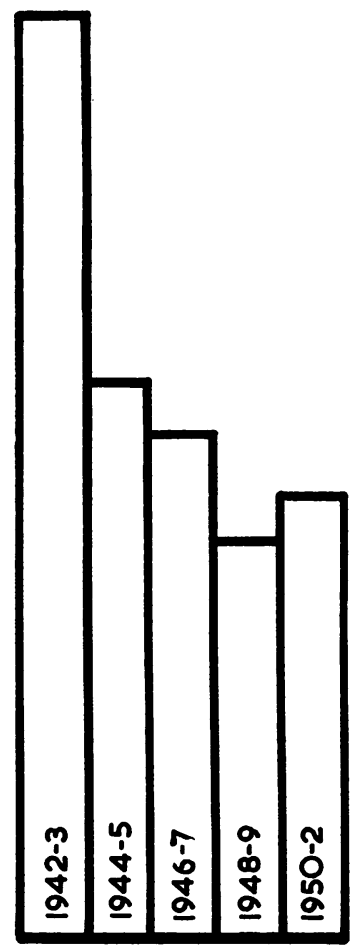

TYPES 3 ond 4

Fig. 3.-Foetal mortality, according to type of placenta praevia. Stillbirths and neonatal deaths per 1,000 total births.

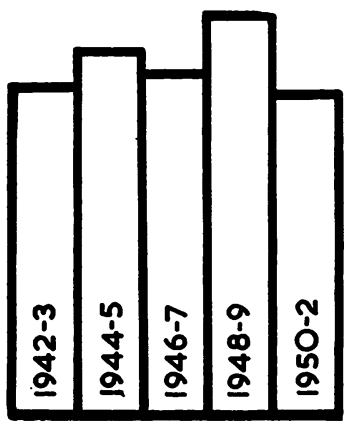

1950-2. Since this result may be influenced by a changed distribution according to maternal age and parity, the mean has been standardized to correct for these variables. This correction has no substantial effect on the conclusion that the average length of pregnancy in cases of placenta praevia increased by about 9 days between 1942-3 and 1950-2 (see also Fig. 4). It seems unlikely that the whole increase can be attributed to expectant treatment, since it appears to have begun before 1945 (Table VIII) when expectant methods were not in general use.

TABLE VIII

SECULAR CHANGES IN DURATION OF PREGNANCIES ASSOCIATED WITH PLACENTA PRAEVIA

\begin{tabular}{|c|c|c|c|c|c|c|}
\hline Year & .. & $1942-3$ & $1944-5$ & $1946-7$ & $1948-9$ & $1950-2$ \\
\hline \multicolumn{2}{|c|}{ No. of Pregnancies } & 89 & 115 & 216 & 188 & 229 \\
\hline \multirow{2}{*}{$\begin{array}{l}\text { Dura- } \\
\text { tion } \\
\text { of } \\
\text { Preg- } \\
\text { nancy }\end{array}$} & Crude mean & $254 \cdot 1$ & $258 \cdot 2$ & $259 \cdot 5$ & $262 \cdot 7$ & $262 \cdot 8$ \\
\hline & $\begin{array}{l}\text { Mean stan- } \\
\text { dardized for } \\
\text { maternal age } \\
\text { and parity.. }\end{array}$ & $254 \cdot 9$ & $258 \cdot 2$ & $259 \cdot 4$ & $262 \cdot 8$ & $263 \cdot 5$ \\
\hline
\end{tabular}

During the period 1942-52 there has also been an increase in the proportion of abdominal deliveries (Fig. 4, overleaf). We have attempted to assess the relative contribution of these two changes-prolonged duration of gestation and increased use of Caesarean delivery- to the decline of foetal mortality. Table IX gives the crude death rates in 1942-7 and 1948-52, and shows the expected reduction in mortality resulting from the increase in abdominal deliveries, and the increased duration of gestation.

TABLE IX

ASSESSMENT OF CONTRIBUTION OF PROLONGED GESTATION AND METHOD OF DELIVERY TO DECLINE IN FOETAL MORTALITY

\begin{tabular}{|c|c|c|c|}
\hline Year & $1942-7$ & $1948-52$ & Difference \\
\hline Crude Foetal Mortality Rates .. & 272 & 202 & 70 \\
\hline $\begin{array}{l}\text { Applying } 1942-52 \text { rates to each } \\
\text { series distributed according to } \\
\text { mode of delivery .. }\end{array}$ & 249 & 227 & 22 \\
\hline $\begin{array}{l}\text { Applying } 1942-52 \text { rates to each } \\
\text { series distributed according to } \\
\text { duration of gestation } \ldots\end{array}$ & 256 & 219 & 37 \\
\hline
\end{tabular}

The results suggest that a little less than one-third of the reduction of foetal mortality can be accounted for by increased use of Caesarean delivery, and about one-half by the prolongation of gestation which has been brought about by expectant treatment. Almost 


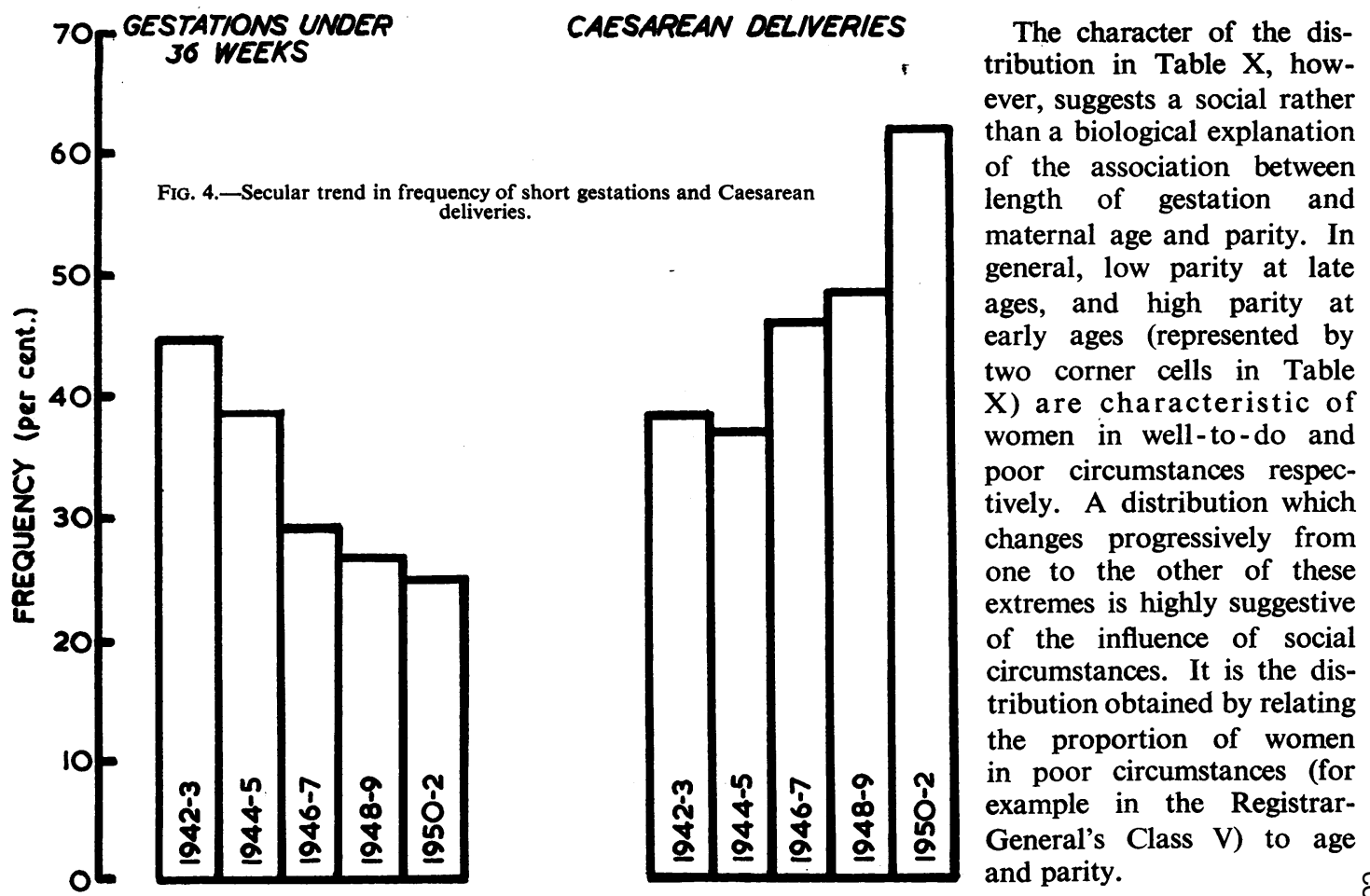
tribution in Table $\mathrm{X}$, however, suggests a social rather than a biological explanation of the association between length of gestation and maternal age and parity. In general, low parity at late ages, and high parity at early ages (represented by two corner cells in Table $X)$ are characteristic of women in well-to-do and tively. A distribution which changes progressively from one to the other of these extremes is highly suggestive of the influence of social ircumstances. It is the distribution obtained by relating the proportion of women nces (for General's Class V) to age and parity.

a quarter of the decine is not attributable to either procedure, and must be due to other influences, such as improved methods of vaginal delivery, and better care of the premature infant.

It may be recalled that Types 3 and 4 showed no decrease in foetal mortality during the period (Fig. 3). This is partly due to the fact that for a number of years it has been usual to treat these cases by Caesarean section (in 1942-3, 86 per cent. of cases were delivered in this way), so that the effect on foetal mortality of a further rise in the frequency of Caesarean section could not be large. But the increase in mean gestation of these cases $(253 \cdot 7$ days in $1942-3$ to $261 \cdot 7$ days in 1950-2) suggests that expectant treatment has been widely used and it is perhaps surprising that this has not resulted in a lower foetal mortality rate.

Investigation of duration of gestation in placenta praevia drew attention to an interesting association with mother's parity and age (Table X). Among women under 35 , the mean period of gestation decreases with increasing parity, to an extent far greater than is observed in normal pregnancy. For example, for women under 25, the mean duration of gestation was 260 days for first births, and 248 for third and later births. The mean period of gestation also increases with age, an effect not observed in normal pregnancy.
If this interpretation is correct, it suggests that $\overline{0}$ duration of gestation in placenta praevia is related to the social circumstances of the mother. The implications of this conclusion are considered later, but before accepting it we must be assured that the results shown in Table $X$ are not due to secular changes in the age-parity distribution. For example, the presence of an undue proportion of young mothers of high parity in the earlier years (when gestations were of shorter duration) could account for this pattern. This possibility was investigated by dividing the series into five groups according to year of delivery $(1942-3,1944-5,1946-7,1948-9$, and 1950-2) and reconstructing Table $X$ on the assumption that the age-parity distribution was the same in each group. This procedure had only a trivial effect on the result.

TABLE X

MEAN DURATION OF GESTATION (DAYS) IN PLACENTA PRAEVIA RELATED TO AGE AND PARITY

\begin{tabular}{|c|c|c|c|c|c|}
\hline \multirow{2}{*}{\multicolumn{3}{|c|}{ Age (yrs) }} & \multicolumn{3}{|c|}{ Parity } \\
\hline & & & 1 & 2 & 3 and over \\
\hline $\begin{array}{l}\text { Under } 25 \\
25- \\
35 \text { and over }\end{array}$ & $\begin{array}{l}\cdots \\
\cdots\end{array}$ & $\ddot{x}$ & $\begin{array}{l}260 \text { (67) } \\
265 \text { (111) } \\
263 \text { (44) }\end{array}$ & $\begin{array}{ll}257 & (32) \\
259 & (154) \\
262 & (59)\end{array}$ & $\begin{array}{l}248 \text { (11) } \\
256 \text { (186) } \\
263 \text { (173) }\end{array}$ \\
\hline
\end{tabular}

No. of cases is given in brackets. 


\section{Discussion}

The contribution of low weight to foetal mortality, and of short gestation and rate of foetal growth to low weight in placenta praevia may perhaps be most readily appreciated by contrasting the results with those obtained in multiple pregnancy. In multiple pregnancy, low birth weight accounts mainly for the increased foetal mortality, since at corresponding weights there are relatively small differences in the death rates of single and multiple births (Record, Gibson, and McKeown, 1952). In placenta praevia, low birth weight accounts for only about 40 per cent. of the increased mortality, the remainder being attributable to other causes, such as asphyxia and haemorrhage, and, to a small extent, to a raised incidence of congenital malformations.

In multiple pregnancy the low birth weight is due partly to early onset of labour, and partly to retardation of foetal growth; the second influence is much more important than the first. In placenta praevia retardation of foetal growth is responsible for only a small part of the reduction of weight, which must be attributed mainly to short gestation. This observation underlines the importance of recent attempts to reduce mortality by expectant treatment which has as its objective the prolongation of pregnancy.

We have attempted to assess the contribution of expectant treatment to the reduction of foetal mortality. In Birmingham, during the 11-year period 1942-52, there has been a substantial decline in mortality, and it is estimated that about 50 per cent. of the improvement is due to prolongation of gestation, 30 per cent. to increased use of Caesarean delivery, and the remainder to other influences. Evidence is presented which suggests that the duration of pregnancy in placenta praevia varies according to the social circumstances of the mother, being substantially longer for well-to-do than for poor women. This observation is, perhaps, worth further consideration. Duration of gestation in placenta praevia depends on a number of factors, of which the most relevant are:

(a) The stage which the pregnancy has reached when the bleeding starts.

(b) The interval between the onset of bleeding and admission to hospital.

(c) The treatment adopted in hospital.

It is possible that all three are influenced by the social and economic circumstances of the patient. Women of low social class may bleed at an earlier stage than women with a similar type of placenta praevia living under good conditions. The initial bleeding may also be more severe or more persistent among women in poor circumstances, causing them to be admitted to hospital earlier. Having entered hospital, they may be unable to accept the expectant methods of treatment which might necessitate a prolonged stay. The data available from the present inquiry do not permit an exploration of these possibilities. The difference of 15 days between the mean duration of gestation of primiparae aged 35 and over and that of mothers of third and later children aged under 25 (263 and 248 days respectively) provides an indication of improvement which it may be possible to achieve.

\section{SUMMARY}

(1) Data relating to 971 cases of placenta praevia occurring in single pregnancies treated in Birmingham hospitals in the years 1942-52 were analysed. The foetal mortality rate was 238 per 1,000 . The rate for all Birmingham single births in 1947 was 39 per 1,000 .

(2) Mean foetal weight was $6 \cdot 30 \mathrm{lb}$. for births associated with placenta praevia and $7 \cdot 16 \mathrm{lb}$. for Birmingham hospital single births. The low birth weight accounted for about half the increased foetal mortality in placenta praevia. It was mainly attributable to early delivery and only slightly to a retarded rate of foetal growth.

(3) During the period there was a substantial fall in foetal mortality (from 345 per 1,000 in 1942-3 to 181 per 1,000 in 1950-52). About one-half of this reduction was attributable to prolongation of gestation and a little less than one-third to increased use of Caesarean section.

(4) Examination of duration of gestation in relation to age and parity suggested that delivery occurred earlier among women in poor circumstances than among those living under better conditions.

We gratefully acknowledge our indebtedness to the staffs of the Birmingham maternity hospitals for permitting access to their records and to Miss Ida Giles and Miss Patricia Hobson for abstracting the data.

\section{REFERENCES}

Beilly, J. S., Greenberg, M. W., Aaron, J. B., and Peck, S. J. (1952). Amer. J., Obstet. Gynec., 63, 414.

Colmeiro-Laforet, K. (1953). Arch. Gynäk., 183, 167

Gibson, J. R., and McKeown, T. (1950). British Journal of Social Medicine, 4, 221.

Johid., 5, 177.

Johnson, H. W. (1945). Amer. J. Obstet. Gynec., 50, 248.

Macafee, C. H. G. (1945). J. Obstet. Gynaec. Brit. Emp., 52, 313.

McKeown, T.; and Record, R. G. (1953). J. Endocr., 10, 73.

Mills, W. G. (1948). Brit. med. J., $2,896$.

Record, R. G., Gibson, J. R., and McKeown, T. (1952). J. Obstet. Gynaec. Brit. Emp., 59, 471. 